\title{
Influence of estrous cycle hormonal fluctuations and gonadal hormones on the ventilatory response to hypoxia in female rats
}

\author{
Danuzia A. Marques ${ }^{1}$ - Débora de Carvalho ${ }^{2}$ - Glauber S. F. da Silva ${ }^{1}$. \\ Raphael E. Szawka ${ }^{3}$ - Janete A. Anselmo-Franci ${ }^{4}$ Kênia C. Bícego ${ }^{1}$. \\ Luciane H. Gargaglioni ${ }^{1}$
}

Received: 16 May 2017 / Revised: 18 June 2017 / Accepted: 19 June 2017 / Published online: 28 June 2017

(C) Springer-Verlag GmbH Germany 2017

\begin{abstract}
Sex hormones may influence many physiological processes. Recently, we demonstrated that hormonal fluctuations of cycling female rats do not affect respiratory parameters during hypercapnia. However, it is still unclear whether sex hormones and hormonal fluctuations that occur during the estrous cycle can affect breathing during a hypoxic challenge. Our study aimed to evaluate respiratory, metabolic, and thermal responses to hypoxia in female rats on different days of the estrous cycle (proestrus, estrus, metestrus, and diestrus) and in ovariectomized rats that received replacement with oil $(\mathrm{OVX})$, estradiol $\left(\mathrm{OVX}+\mathrm{E}_{2}\right)$, or a combination of estradiol and progesterone $\left(\mathrm{OVX}+\mathrm{E}_{2} \mathrm{P}\right)$. Ventilation $\left(V_{\mathrm{E}}\right)$, tidal volume $\left(V_{\mathrm{T}}\right)$, respiratory frequency (fR), oxygen consumption $\left(\mathrm{VO}_{2}\right)$, and $V_{\mathrm{E}} / \mathrm{VO}_{2}$ were not different during the estrous cycle in normoxia or hypoxia. Body temperature $(\mathrm{Tb})$ was higher during estrus, but decreased similarly in all groups during hypoxia. Compared with intact females in estrus, gonadectomized rats also had lower Tb in normoxia, but not in hypoxia. OVX rats experienced a significant drop in the ventilatory response to hypoxia, but hormonal replacement did not restore values to the levels of an intact animal. Our data demonstrate that the
\end{abstract}

Luciane H. Gargaglioni

lucihel@fcav.unesp.br

1 Department of Animal Morphology and Physiology, São Paulo State University, UNESP FCAV at Jaboticabal, São Paulo, Brazil

2 Federal Institute of Para, Para, Brazil

3 Department of Physiology and Biophysics, Institute of Biological Sciences, Federal University of Minas Gerais, Minas Gerais, Brazil

4 Department of Morphology, Stomatology and Physiology, Dental School of Ribeirao Preto, University of São Paulo, São Paulo, Brazil different phases of the estrous cycle do not alter ventilation during normoxia and hypoxia, but OVX animals display lower ventilatory responses to hypoxia compared with ovaryintact rats. Because estradiol and progesterone replacement did not cause significant differences in ventilation, our findings suggest that a yet-to-be-defined non-steroidal ovarian hormone is likely to stimulate the ventilatory responses to hypoxia in females.

Keywords Estrous cycle $\cdot$ Sex hormones $\cdot$ Breathing $\cdot$ Body temperature $\cdot$ Castration $\cdot$ Hormone replacement

\section{Introduction}

Natural fluctuations in circulating sexual hormones across the estrous and menstrual cycles might be associated with changes in breathing $[29,56]$. Throughout life, estrogen $\left(E_{2}\right)$ and progesterone $(\mathrm{P})$ influence the respiratory function of animals and human beings $[4,12,45]$. In women, during the luteal phase (LP), significant increases in circulating $\mathrm{P}$ and $\mathrm{E}_{2}$ occur, ventilation and tidal volume increase $[12,38,41]$, and the central and peripheral chemosensitivity to hypercapnia and hypoxia are increased, compared to the follicular phase (when $\mathrm{P}$ levels are lowest) $[14,15,38,53]$.

Recently, we demonstrated that despite the hormonal fluctuations during the estrous cycle, the ventilatory response to $\mathrm{CO}_{2}$ in female rats is similar along the cycle [30]. Interestingly, we found that ovariectomy promoted an attenuation (43\%) of the hypercapnic hyperventilation, compared with the response obtained from intact animals in estrus [30]. However, hormonal replacement with $\mathrm{E}_{2}$ or $\mathrm{E}_{2}$ and $\mathrm{P}$ did not restore the effects of ovariectomy on $\mathrm{CO}_{2}$ chemosensitivity. 
Combined action of $E_{2}$ and $P$ reduces the occurrence of respiratory disorders like sleep obstructive apnea $[8,36]$, but the mechanisms of action and the effects of ovarian steroids are not yet fully elucidated. It is suggested that $E_{2}$ 's main actions are mediated primarily through the activation of intracellular estrogen receptors, which are distributed throughout multiple organs, such as the uterus, breast, ovary, lungs, kidneys, bones, and brain [7,33]. Estrogen and progesterone receptors are also found in the carotid body of adult and neonate rats [23] where they exert an excitatory effect on baseline activity and hypoxic chemoresponsiveness [19, 25, 46, 47], and are, therefore, potential protective factors against the occurrence of sleep apneas in women [36, 39, 55].

The vast majority of studies in respiratory physiology use rats as the experimental model, with males being the preferred gender. When females are used in studies, authors frequently do not take into account the wide variations in circulating hormonal levels that occur during the estrous cycle. This last consideration has emerged as an important factor to be considered when working with female animals in clinical scenarios and in several research areas [40]. Several studies have demonstrated that the ventilatory responses to hypoxia in women vary during the different phases of the menstrual cycle, showing that hormonal fluctuations may be important and should be considered [13, 14, 16, 29, 44, 53]. Despite the studies that investigated the women's menstrual cycles, only a few studies have examined the influence of the estrous cycle on breathing in animal models [52]. As far as we are concerned, it remains to be explored whether the hormonal fluctuations of the estrous cycle affect the hypoxic ventilatory response, and what the potential effects of ovariectomy might have on the peripheral chemoreflex. In addition to the hormonal influence on ventilatory responses, it has been reported that $E_{2}$ is also involved in the regulation of body temperature (Tb) $[5,32]$ in both animal models and in women. Many periand post-menopausal women suffer from face-flushing, sweating, and hotness with a reduction of body temperature. Although $E_{2}$ is unlikely to be the sole factor involved, a replacement with estrogen is often used as a therapy [49].

Given the data in the literature, we hypothesized that hormonal fluctuations observed throughout the rat estrous cycle would have an impact on the ventilatory, metabolic, and body temperature regulation during hypoxia. We also evaluated the possible role of $\mathrm{E}_{2}$ and $\mathrm{P}$ in these physiological responses to hypoxia.

\section{Materials and methods}

\section{Animals}

Experiments were performed on conscious, adult female Wistar rats, weighing 250-300 g. The animals had free access to water and food and were housed in a temperature-controlled chamber at $24-26^{\circ} \mathrm{C}$ (ALE 9902001; Alesco, Monte Mor, SP, Brazil) with a 12:12 h light/dark cycle (lights on at 6:00 a.m.). Animal care was carried out in compliance with the Brazilian College of Animal Experimentation guidelines and approved by the local Animal Care and Use Committee (protocol no. 007827-09). We used cycling female rats on the days of proestrus $(n=7)$, estrus $(n=6)$, metestrus $(n=6)$, and diestrus $(n=5)$, and OVX rats treated with corn oil $(\mathrm{OVX}+\mathrm{O} ; n=5)$, $\mathrm{E}_{2}\left(\mathrm{OVX}+\mathrm{E}_{2} ; n=6\right)$ or a combination of $\mathrm{E}_{2}$ and $\mathrm{P}(\mathrm{OVX}+$ $\left.\mathrm{E}_{2} \mathrm{P} ; n=4\right)$.

\section{Determination of the estrous cycle}

Vaginal smears were taken daily to verify the regularity of the estrous cycle, and only those rats showing at least five consecutive regular 4- or 5-day estrous cycles were included in the study. The wet smears were collected at 9:00 a.m., immediately rolled onto a glass slide and allowed to air dry. Slides were examined for the following features: cornified epithelial cells, nucleated epithelial cells, and leukocytes. Estrous cycle stages were then determined using the following criteria: (1) proestrus, predominantly nucleated epithelial cells; (2) estrus, predominantly cornified epithelial cells; (3) metestrus, presence of nucleated cells, but predominantly leukocytes; and (4) diestrus: predominantly leukocyte cells $[18,30]$.

\section{Surgical procedures}

Animals were anesthetized with a solution of ketamine $(100 \mathrm{mg} / \mathrm{kg}$, i.p.; Agener, São Paulo, Brazil) and xylazine (10 mg/kg, i.p.; Coopers, São Paulo, Brazil) to perform the ovariectomy and the implantation of a temperature datalogger (SubCue, Calgary, AB, Canada) in the abdominal cavity. At the end of surgery, the animals were treated with antibiotics $(10 \mathrm{mg} / \mathrm{kg}$, s.c.; Enrofloxacin, Flotril, Schering-Plough, São Paulo, Brazil) and analgesic $(2.5 \mathrm{mg} / \mathrm{kg}$, s.c.; flunixin meglumine, Banamine, Schering-Plough, São Paulo, Brazil).

\section{Ovariectomy and hormonal replacement}

Ovariectomy was performed as previously described [30]. A 3-cm-long midline dorsal skin incision was made approximately halfway between the middle of the back and the base of the tail. After the peritoneal cavity was accessed, the ovary was found surrounded by a variable amount of fat tissue. The connection between the fallopian tube and the uterine horn was cut and the ovary moved out, according to the method described by Lasota and Danowska-Klonowska [28]. Eight days after ovariectomy, rats were treated with corn oil $(0.2 \mathrm{~mL}$, s.c. $)$ or $\mathrm{E}_{2}(10 \mu \mathrm{g} / 0.2 \mathrm{~mL}$, s.c., $17 \beta$-estradiol cypionate; Pfizer, São Paulo, Brazil), at 9 a.m. for 3 days. On the fourth day, oil-treated rats received a final oil injection 
$(\mathrm{OVX}+\mathrm{O}$ group $)$, while $\mathrm{E}_{2}$-treated rats received an injection containing corn oil (OVX $+\mathrm{E}_{2}$ group) or $\mathrm{P}(2.5 \mathrm{mg} / 0.2 \mathrm{~mL}$, s.c., OVX $+\mathrm{E}_{2} \mathrm{P}$ group; Sigma, St. Louis, MO). The hormonal treatment regimens used were found to yield physiological levels of plasma $17 \beta$-estradiol and progesterone [43]. All experiments were conducted on day 8 following ovariectomy. On the day of experiment, vaginal cytology was performed to monitor the effectiveness of the hormonal treatment, as described in Marques et al. [30]. Estrus is the phase of the estrous cycle in which gonadal hormones are found to be in their lowest concentrations [42]. Here, we considered estrus to be a control for comparison with OVX animals.

\section{Determination of pulmonary ventilation, body temperature, and metabolism}

Measurements of ventilation were taken by the wholebody plethysmography method [2], and $\mathrm{Tb}$ was recorded by use of a temperature datalogger (SubCue, Calgary, AB, Canada) implanted within the abdominal cavity and programmed to acquire data every $5 \mathrm{~min}$, as previously described in the literature $[6,11,30]$. Two respiratory variables, fR and $V_{\mathrm{T}}$, were measured. $V_{\mathrm{T}}$ was calculated by the equations provided by Bartlett and Tenney [2], and $V_{\mathrm{E}}$ was calculated by the product of $\mathrm{fR}$ and $V_{\mathrm{T}}$. Freely-moving rats were kept in a 5 -L chamber ventilated with either room air or a hypoxic gas mixture containing $7 \% \quad \mathrm{O}_{2}$ (White Martins, Sertãozinho, Brazil). The flow rate $\left(1.5 \mathrm{~L} \mathrm{~min}^{-1}\right)$ of the gas into the animal chamber was monitored by a flowmeter (model 822-13-OV1-PV2-V4; Sierra Instruments, Monterey, CA, USA). $V_{\mathrm{E}}$ was calculated before (time zero) and $30 \mathrm{~min}$ after hypoxia exposure. During measurement, the flow was interrupted and the chamber sealed for short periods of time ( $\sim 1 \mathrm{~min})$; pressure oscillations due to respiration were monitored by a differential pressure transducer (TSD 160A; Biopac Systems, Santa Barbara, CA, USA). The signals were fed into a differential pressure transducer (DA 100C; Biopac Systems), passed through an analog-to-digital converter and digitized on a microcomputer equipped with data acquisition software (MP100A-CE; Biopac Systems). The sampling frequency was 200 samples per second. The results were analyzed using the data analysis software, Acknowledge (v3.8.1 data acquisition system; Biopac Systems). Calibration for volume was obtained during each experiment by injecting the animal chamber with $1 \mathrm{~mL}$ of air.

Metabolic rate was calculated by an indirect calorimetry method, using a closed respirometry system [1, 30]. Following gas exposure (normoxia or hypoxia), the air flow of the chamber was interrupted for $2 \mathrm{~min}$ and the air was continuously sampled by an $\mathrm{O}_{2}$ analyzer (PowerLab System,
ADInstruments $\AA^{-C h a r t ~ S o f t w a r e, ~ v e r s i o n ~ 7.3 . ~ S y d n e y, ~}$ Australia). The decline in $\mathrm{O}_{2}$ concentration during the 2-min interval was used to calculate $\mathrm{VO}_{2}$. Values were presented in milliliters per minute per kilogram in standard conditions of temperature, pressure, and dry air (STPD). All experiments were performed between 9:00 a.m. and 1:00 p.m. to minimize any influence of circadian rhythms.

\section{Statistical analyses}

$V_{\mathrm{E}}, \mathrm{fR}, V_{\mathrm{T}}, \mathrm{Tb}$, and $\dot{\mathrm{VO}}_{2}$ were compared among groups using two-way ANOVA for repeated measures. The significance level was set to $P<0.05$. The statistical analyses were performed using computer software (Sigma Stat; Systat Software, Point Richmond, CA, USA). Data are presented as group means \pm SEM for each parameter investigated.

\section{Results}

Ventilatory, metabolic, and body temperature data for different phases of the estrous cycle, and the comparisons of OVX, $\mathrm{OVX}+\mathrm{E}_{2}$, and $\mathrm{OVX}+\mathrm{E}_{2} \mathrm{P}$ animals with intact animals in the estrous phase, during normoxia and hypoxia are shown in Tables 1 and 2 .

\section{Estrous cycle: ventilation, body temperature, and metabolism in normoxia and hypoxia}

\section{Ventilation}

In normoxic conditions, no differences in $V_{\mathrm{E}}$ were observed in the four different phases of the estrous cycle. Hypoxia caused an increase in $V_{\mathrm{E}}$ in all groups [hypoxia effect: $P<0.0001$; $F_{(3,20)}=133.7$; without interaction], resulting from a combination of $V_{\mathrm{T}}$ [hypoxia effect: $P<0.0001 ; F_{(3,20)}=98.3$; without interaction] and fR [hypoxia effect: $P<0.0001$; $F_{(3,20)}=75.9$; without interaction]. However, there was no difference among groups, as shown in Fig. 1.

\section{Metabolism}

In normoxic conditions, no differences in $\mathrm{VO}_{2}$ and $V_{\mathrm{E}} / \mathrm{VO}_{2}$ were observed in the different phases of the estrous cycle (Fig. 2). Hypoxia caused a decrease in $\mathrm{VO}_{2}$ in all groups [hypoxia effect: $P<0.0001 ; F_{(3,20)}=491.6$; without interaction] and a significant increase in the $V_{\mathrm{E}} / \mathrm{VO}_{2}$ [hypoxia effect: $P<0.0001 ; F_{(3,20)}=227.9$; without interaction], and no difference was found among groups. 
Table 1 Ventilatory, metabolic, and body temperature data for different phases of estrous cycle during normoxia and hypoxia conditions

\begin{tabular}{lcccc}
\hline & Proestrus & Estrus & Metaestrus & Diestrus \\
\hline$n$ & 7 & 6 & 6 & 5 \\
Weight $(\mathrm{g})$ & $255.9 \pm 9.7$ & $276.2 \pm 9.7$ & $292.0 \pm 6.4$ & $260.4 \pm 10.5$ \\
Normoxia & & & \\
$\quad \dot{V}_{\mathrm{E}}\left(\mathrm{mL} \mathrm{kg}^{-1} \mathrm{~min}^{-1}\right)$ & $589.4 \pm 36.4$ & $593.7 \pm 70.5$ & $535.2 \pm 60.2$ & $552.9 \pm 59.1$ \\
$\dot{V}_{\mathrm{T}}\left(\mathrm{mL} \mathrm{kg}^{-1}\right)$ & $7.1 \pm 0.6$ & $7.5 \pm 0.8$ & $6.4 \pm 0.5$ & $7.5 \pm 0.4$ \\
$f\left(\mathrm{breath} \mathrm{min}^{-1}\right)$ & $84.4 \pm 5.6$ & $79.2 \pm 6.4$ & $82.7 \pm 5.5$ & $73.8 \pm 6.0$ \\
$\dot{\mathrm{VO}}_{2}\left(\mathrm{~mL} \mathrm{~kg}^{-1} \mathrm{~min}^{-1}\right)$ & $19.8 \pm 0.5$ & $19.6 \pm 0.8$ & $18.3 \pm 0.6$ & $19.1 \pm 1.1$ \\
$\dot{V}_{\mathrm{E}} / \mathrm{VO}_{2}$ & $29.8 \pm 1.9$ & $30.2 \pm 3.2$ & $29.8 \pm 4.1$ & $29.8 \pm 4.3$ \\
$\left.\mathrm{~Tb}^{\circ}{ }^{\circ} \mathrm{C}\right)$ & $37.2 \pm 0.2$ & $38.1{ }^{\mathrm{a}} \pm 0.1$ & $37.4 \pm 0.1$ & $37.2 \pm 0.1$ \\
$\mathrm{Hypoxia}$ & & & & \\
$\dot{V}_{\mathrm{E}}\left(\mathrm{mL} \mathrm{kg}^{-1} \mathrm{~min}^{-1}\right)$ & $1410.3 \pm 96.5$ & $1567.7 \pm 99.0$ & $1517.2 \pm 153.1$ & $1442.2 \pm 248.5$ \\
$\dot{V}_{\mathrm{T}}\left(\mathrm{mL} \mathrm{kg}^{-1}\right)$ & $12.8 \pm 1.0$ & $13.9 \pm 0.7$ & $13.0 \pm 1.2$ & $13.9 \pm 1.6$ \\
$f\left(\mathrm{breath} \mathrm{min}^{-1}\right)$ & $110.3 \pm 2.1$ & $112.7 \pm 2.6$ & $117.0 \pm 9.1$ & $102.4 \pm 9.2$ \\
$\dot{\mathrm{VO}}_{2}\left(\mathrm{~mL} \mathrm{~kg}^{-1} \mathrm{~min}^{-1}\right)$ & $11.0 \pm 0.5$ & $10.7 \pm 0.7$ & $10.7 \pm 0.4$ & $11.5 \pm 0.5$ \\
$\dot{V}_{\mathrm{E}} / \dot{\mathrm{VO}}_{2}$ & $130.7 \pm 11.6$ & $155.5 \pm 13.74$ & $142.4 \pm 14.9$ & $124.8 \pm 19.2$ \\
$\left.\mathrm{~Tb}^{\circ}{ }^{\circ} \mathrm{C}\right)$ & $35.7 \pm 0.2$ & $36.0 \pm 0.3$ & $35.7 \pm 0.1$ & $35.5 \pm 0.3$ \\
\hline
\end{tabular}

Values are mean \pm SE. $P<0.05$

$n$ no. of rats

${ }^{a}$ Difference of estrus vs proestrus, diestrus, and metaestrus

\section{Body temperature}

$\mathrm{Tb}$ of rats in estrus was higher than in other phases of the estrous cycle during normoxia [cycle effect: $P=0.0022$,
$F_{(3,20)}=4.0$; without interaction]. Hypoxia caused a decrease in Tb in all groups [hypoxia effect: $P<0.0001 ; F_{(3,20)}=173.3$; without interaction] but there was no difference among them, as shown in Fig. 3.
Table 2 Ventilatory, metabolic, and body temperature data comparing OVX, OVX $+\mathrm{E}_{2}$, and $\mathrm{OVX}+\mathrm{E}_{2} \mathrm{P}$ animals with intact animal in estrus phase, in normoxia and hypoxia conditions

\begin{tabular}{lcccc}
\hline & Estrus & $\mathrm{OVX}+\mathrm{O}$ & $\mathrm{OVX}+\mathrm{E}_{2}$ & $\mathrm{OVX}+\mathrm{E}_{2} \mathrm{P}$ \\
\hline$n$ & 6 & 5 & 6 & 4 \\
Weight $(\mathrm{g})$ & $276.2 \pm 9.7$ & $289.4 \pm 12.9$ & $299.7 \pm 10.2$ & $302.0 \pm 3.3$ \\
Normoxia & & & \\
$\dot{V}_{\mathrm{E}}\left(\mathrm{mL} \mathrm{kg}^{-1} \mathrm{~min}^{-1}\right)$ & $593.7 \pm 70.5$ & $397.9 \pm 17.8$ & $468.9 \pm 32.7$ & $417.1 \pm 37.0$ \\
$\dot{V}_{\mathrm{T}}\left(\mathrm{mL} \mathrm{kg}^{-1}\right)$ & $7.5 \pm 0.8$ & $5.3 \pm 0.6$ & $6.0 \pm 0.3$ & $5.4 \pm 0.5$ \\
$f\left(\mathrm{breath} \mathrm{min}^{-1}\right)$ & $79.2 \pm 6.4$ & $78.2 \pm 7.1$ & $79.0 \pm 4.2$ & $77.5 \pm 3.9$ \\
$\dot{\mathrm{VO}}_{2}\left(\mathrm{~mL} \mathrm{~kg}^{-1} \mathrm{~min}^{-1}\right)$ & $19.6 \pm 0.8$ & $17.6 \pm 0.6$ & $18.1 \pm 0.8$ & $17.6 \pm 0.4$ \\
$\dot{V}_{\mathrm{E}} / \mathrm{VO}_{2}$ & $30.2 \pm 3.2$ & $23.1 \pm 0.9$ & $27.7 \pm 2.5$ & $26.1 \pm 1.8$ \\
${\mathrm{~Tb}\left({ }^{\circ} \mathrm{C}\right)}_{\mathrm{Hypoxia}}$ & $37.2^{\mathrm{a}, \mathrm{b}, \mathrm{c}} \pm 0.2$ & $37.3 \pm 0.2$ & $37.4 \pm 0.2$ & $37.2 \pm 0.3$ \\
$\dot{V}_{\mathrm{E}}\left(\mathrm{mL} \mathrm{kg}^{-1} \mathrm{~min}^{-1}\right)$ & $1567.7^{\mathrm{a}, \mathrm{b}} \pm 99.0$ & $895.1 \pm 42.1$ & $1020.0 \pm 88.6$ & $1112.8 \pm 75.0$ \\
$\dot{V}_{\mathrm{T}}\left(\mathrm{mL} \mathrm{kg}^{-1}\right)$ & $13.9^{\mathrm{a}, \mathrm{b}} \pm 0.7$ & $7.5 \pm 0.5$ & $9.3 \pm 0.8$ & $9.6 \pm 1.1$ \\
$f(\mathrm{breaths} \mathrm{min}$ & & & & \\
$\dot{\mathrm{VO}}_{2}\left(\mathrm{~mL} \mathrm{~kg}^{-1} \mathrm{~min}^{-1}\right)$ & $112.7 \pm 2.6$ & $110.8 \pm 2.5$ & $109.8 \pm 3.3$ & $118.5 \pm 6.7$ \\
$\dot{V}_{\mathrm{E}} / \dot{\mathrm{VO}}_{2}$ & $10.7 \pm 0.7$ & $10.3 \pm 0.2$ & $10.7 \pm 0.2$ & $11.0 \pm 0.7$ \\
$\mathrm{~Tb}^{\circ}\left({ }^{\circ} \mathrm{C}\right)$ & $155.5^{\mathrm{a}, \mathrm{b}, \mathrm{c}} \pm 13.7$ & $86.8 \pm 3.9$ & $96.3 \pm 9.5$ & $102.1 \pm 7.7$ \\
\hline
\end{tabular}

Values are mean \pm SE. $P<0.05$

$n$ no. of rats

${ }^{a}$ Difference estrus vs OVX

${ }^{\mathrm{b}}$ Difference estrus vs OVX $+\mathrm{E}_{2}$

${ }^{c}$ Difference estrus vs OVX $+\mathrm{E}_{2} \mathrm{P}$ 

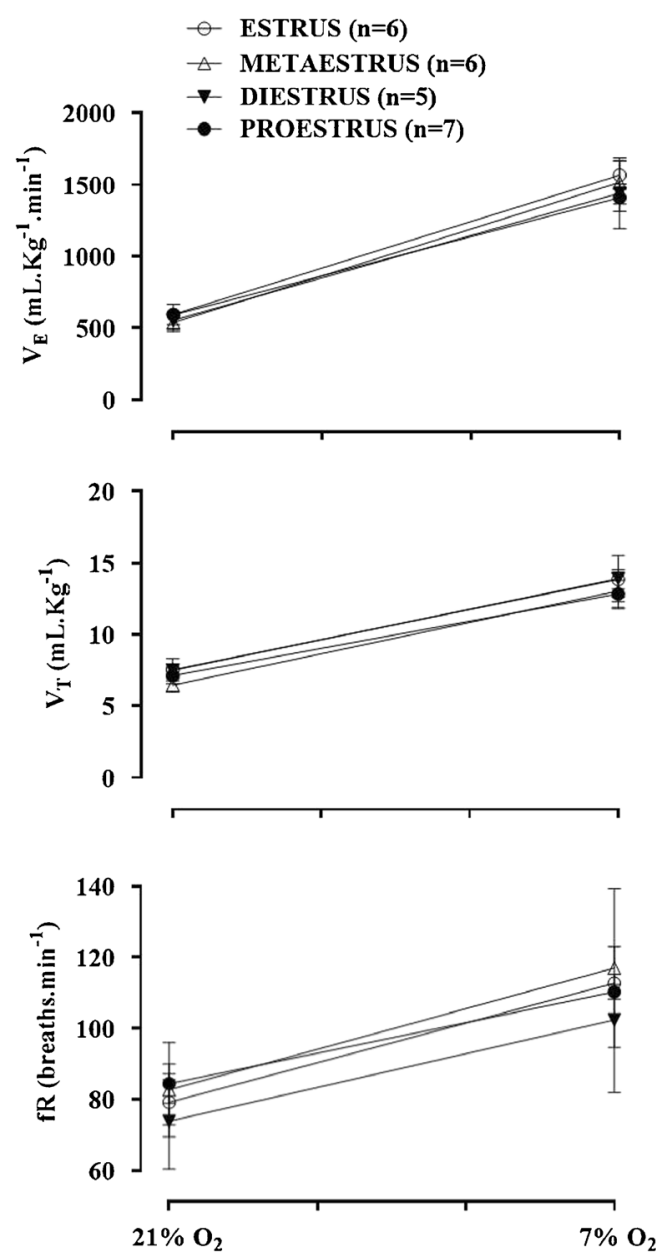

Fig. 1 Ventilation $\left(V_{\mathrm{E}}\right)$, tidal volume $\left(V_{\mathrm{T}}\right)$, and respiratory frequency (fR) of rats in proestrus, estrus, metaestrus, and diestrus during normoxia ( $21 \%$ $\left.\mathrm{O}_{2}\right)$ and hypoxia $\left(7 \% \mathrm{O}_{2}\right)$

\section{Ovariectomy and hormonal replacement: ventilation, body temperature, and metabolism in normoxia and hypoxia}

\section{Ventilation}

Comparing OVX animals, treated or not with ovarian steroids, with cycling rats in estrus in normoxia, there was no significant difference in ventilatory parameters among groups (Fig. 4). Hypoxia caused a significant increase in $V_{\mathrm{E}}$ in all groups [effect of hypoxia: $P<0.0001, F_{(3,18)}=169.3$ ], resulting from a combination of increased $V_{\mathrm{T}}$ [effect of hypoxia: $P<0.0001$, $F_{(3,18)}=69.3$; effect of OVX: $P<0.0001$; interaction among groups: $P<0.05$ ] and fR [effect of hypoxia: $P<0.0001$, $F_{(3,18)}=72.6$; no OVX effect, and no significant interaction]. Nevertheless, $\mathrm{OVX}+\mathrm{O}, \mathrm{OVX}+\mathrm{E}_{2}$, and $\mathrm{OVX}+\mathrm{E}_{2} \mathrm{P}$ showed an attenuated hypoxic ventilatory response, compared to rats in estrus [effect of castration: $P<0.0001, F_{(3,18)}=18.9$; interaction among groups: $P=0.014$ ] (Fig. 4).
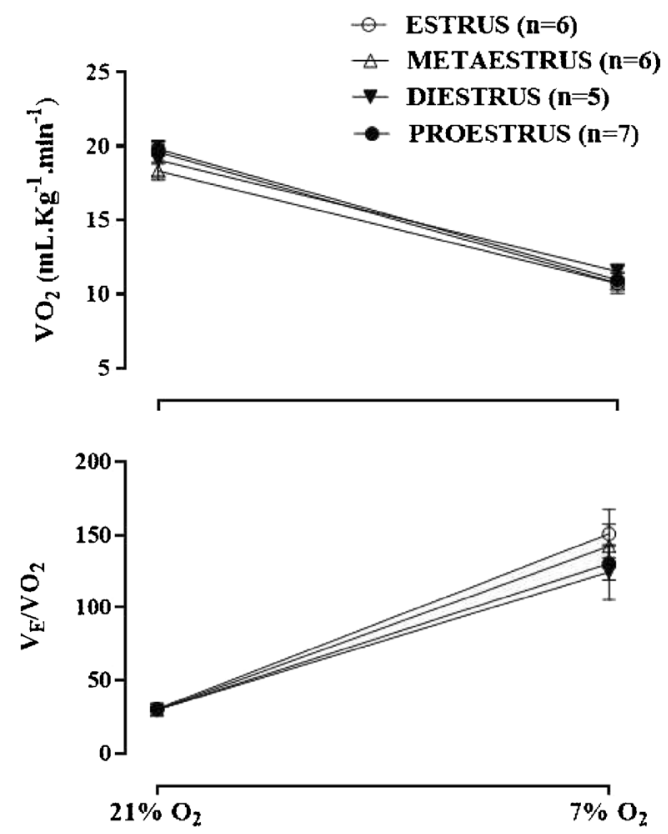

Fig. 2 Oxygen consumption $\left(\mathrm{VO}_{2}\right)$ and respiratory equivalent $\left(V_{\mathrm{E}} / \mathrm{VO}_{2}\right)$ of rats in proestrus, estrus, metaestrus, and diestrus during normoxia $(21 \%$ $\left.\mathrm{O}_{2}\right)$ and hypoxia $\left(7 \% \mathrm{O}_{2}\right)$

\section{Metabolism}

As seen in Fig. 5, during normoxic conditions, no differences in $\mathrm{VO}_{2}$ were observed in OVX rats $(\mathrm{OVX}+\mathrm{O}$, $\mathrm{OVX}+\mathrm{E}_{2}$, and $\left.\mathrm{OVX}+\mathrm{E}_{2} \mathrm{P}\right)$ compared to intact rats in estrus $(P=0.18)$. Hypoxia caused a decrease in $\mathrm{VO}_{2}$ in all groups [hypoxia effect: $P<0.0001 ; F_{(3,18)}=452.8$; without interaction]. $V_{\mathrm{E}} / \mathrm{VO}_{2}$ was not different between estrous and OVX animals during normoxia. Hypoxia caused an increase in this equivalent in all groups [hypoxia effect: $P<0.0001 ; F_{(3,18)}=266.3$; with interaction: $\left.P=00014 ; F_{(3,18)}=8.2\right]$ with rats in estrus displaying a higher $V_{\mathrm{E}} / \mathrm{VO}_{2}$ response compared to all OVX groups $\left[P<0.001 ; F_{(3,18)}=10.2\right]$.

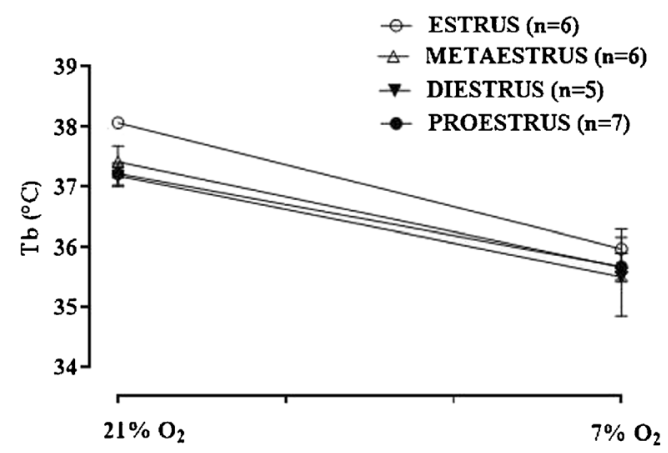

Fig. 3 Body temperature (Tb) of rats in proestrus, estrus, metaestrus, and diestrus during normoxia $\left(21 \% \mathrm{O}_{2}\right)$ and hypoxia $\left(7 \% \mathrm{O}_{2}\right)$ 

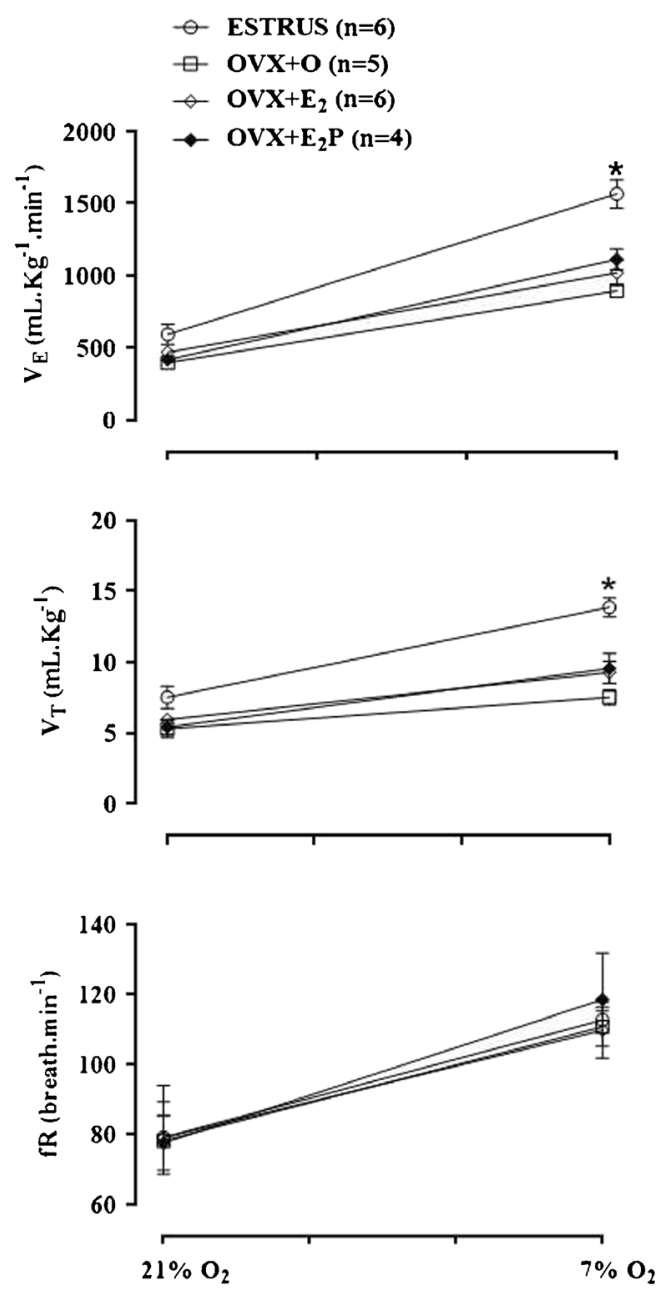

Fig. 4 Ventilation $\left(V_{\mathrm{E}}\right)$, tidal volume $\left(V_{\mathrm{T}}\right)$, and respiratory frequency (fR) of intact rats in estrus, ovariectomized (OVX) with corn oil replacement $(\mathrm{OVX}+\mathrm{O})$, OVX rats replaced with $17 \beta$-estradiol $\left(\mathrm{OVX}+\mathrm{E}_{2}\right)$, or a combination of estradiol and progesterone $\left(\mathrm{OVX}+\mathrm{E}_{2} \mathrm{P}\right)$ during normoxia $\left(21 \% \mathrm{O}_{2}\right)$ and hypoxia $\left(7 \% \mathrm{O}_{2}\right)$. Asterisk indicates a difference between the estrus group compared to $\mathrm{OVX}+\mathrm{O}, \mathrm{OVX}+\mathrm{E}_{2}$, and $\mathrm{OVX}+\mathrm{E}_{2} \mathrm{P}$ groups $(P<0.05)$

\section{Body temperature}

During normoxia, the $\mathrm{Tb}$ of rats in estrus was higher than rats in all OVX groups, which did differ among themselves [cycle effect: $\left.P=0.019, F_{(3,18)}=4\right][30]$. Hypoxia decreased Tb in all groups [hypoxia effect: $P<0.0001 ; F_{(3,20)}=111.30$; without interaction] and there were no differences among them, as shown in Fig. 6.

\section{Discussion}

In the current study, we have demonstrated that different phases of the estrous cycle, during which hormonal fluctuations occur, did not promote alterations in $V_{\mathrm{E}}$, and $V_{\mathrm{E}} / \mathrm{VO}_{2}$ during both normoxia and hypoxia. Both ovariectomy and
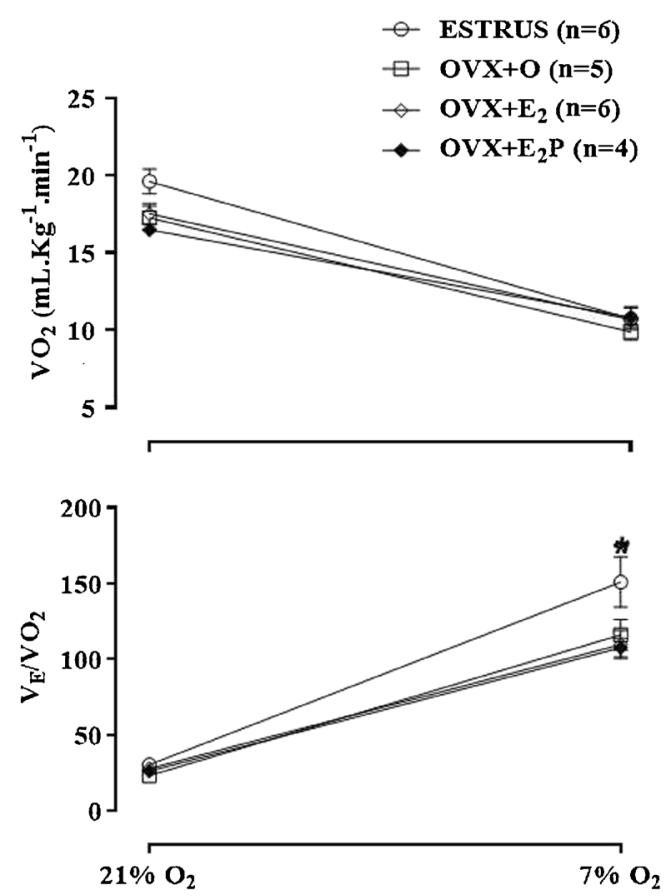

Fig. 5 Oxygen consumption $\left(\mathrm{VO}_{2}\right)$ and respiratory equivalent $\left(V_{\mathrm{E}} / \mathrm{VO}_{2}\right)$ of intact rats in estrus, ovariectomized (OVX) with corn oil replacement $(\mathrm{OVX}+\mathrm{O})$, OVX rats replaced with $17 \beta$-estradiol $\left(\mathrm{OVX}+\mathrm{E}_{2}\right)$, or a combination of estradiol and progesterone $\left(\mathrm{OVX}+\mathrm{E}_{2} \mathrm{P}\right)$ during normoxia $\left(21 \% \mathrm{O}_{2}\right)$ and hypoxia $\left(7 \% \mathrm{O}_{2}\right)$. Asterisk indicates a difference between the estrus group compared to $\mathrm{OVX}+\mathrm{O}, \mathrm{OVX}+\mathrm{E}_{2}$, and OVX $+\mathrm{E}_{2} \mathrm{P}$ groups $(P<0.05)$

ovarian-steroid replacement did not change the ventilation parameters in normoxia. $\mathrm{OVX}+\mathrm{O}, \mathrm{OVX}+\mathrm{E}_{2}$, and $\mathrm{OVX}+$ $\mathrm{E}_{2} \mathrm{P}$ rats showed an attenuated $V_{\mathrm{E}}$, and $V_{\mathrm{E}} / \mathrm{VO}_{2}$ response to hypoxia, compared to estrous animals. The attenuated hypoxic ventilatory response in OVX rats suggests that ovarian hormones likely modulate an excitatory response of the respiratory adjustments to hypoxia. However, replacement with

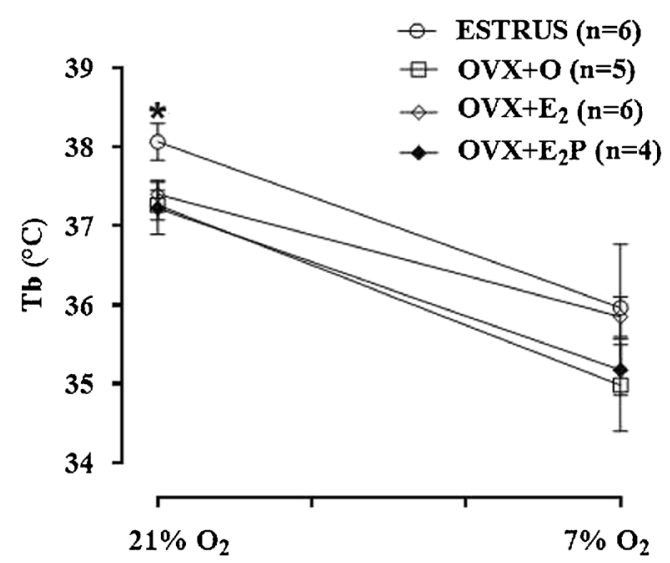

Fig. 6 Body temperature $(\mathrm{Tb})$ of intact rats in estrus, ovariectomized $(\mathrm{OVX})$ with oil replacement $(\mathrm{OVX}+\mathrm{O})$, OVX rats replaced with $17 \beta$ estradiol $\left(\mathrm{OVX}+\mathrm{E}_{2}\right)$, or a combination of estradiol and progesterone $\left(\mathrm{OVX}+\mathrm{E}_{2} \mathrm{P}\right)$ during normoxia $\left(21 \% \mathrm{O}_{2}\right)$ and hypoxia $\left(7 \% \mathrm{O}_{2}\right)$. Asterisk indicates a difference between the estrus group compared to $\mathrm{OVX}+\mathrm{O}, \mathrm{OVX}+\mathrm{E}_{2}$, and $\mathrm{OVX}+\mathrm{E}_{2} \mathrm{P}$ groups $(P<0.05)$ 
physiological levels of $E_{2}$ and $P$ was unable to restore this attenuated response to the level of an intact cycling rat. As demonstrated in previous studies, $\mathrm{Tb}$ was higher in estrus compared to the other phases of the estrous cycle, and with OVX animals $\left(\mathrm{OVX}+\mathrm{O}, \mathrm{OVX}+\mathrm{E}_{2}\right.$, and $\left.\mathrm{OVX}+\mathrm{E}_{2} \mathrm{P}\right)$ during normoxia. During hypoxia, Tb did not change during the estrous cycle and was similar in OVX models and cycling rats in estrous, showing that gonadal hormones do not participate in body temperature regulation during hypoxia.

\section{Estrous cycle: ventilation, body temperature, and metabolism in normoxia and hypoxia}

Studies on ventilatory alterations during the menstrual cycle have demonstrated that the ventilatory response to hypoxia was higher in women in the luteal phase during exercise and resting conditions [3]. Indeed, some studies have reported that peripheral chemoreceptors can be modulated by hormones, such as progesterone $[24,50]$. Conversely, the present data show that estrous cycle fluctuation does not affect the ventilatory response to hypoxia in cycling adult rats. A study by Zabka et al. [56] demonstrated that the short-term ventilatory response to hypoxia in anesthetized rats did not differ among phases of the estrous cycle. Similarly, Marques et al. [30] showed no differences between the ventilatory and metabolic responses in normocapnia and those that are induced by hypercapnia throughout the rat estrous cycle. Herein, our results corroborate these previous studies in the literature, suggesting that compensatory responses exist for these hormonal fluctuations, resulting in the maintenance of ventilation during normoxic and hypoxic conditions in rats.

We also demonstrated an increase in body temperature on the day of estrus, as reported in other studies [26, 30, 54]. In rodents, it is known that there is an increase in Tb immediately before ovulation [35]. In our experiments, $\mathrm{Tb}$ was approximately $0.6{ }^{\circ} \mathrm{C}$ higher during estrus compared to the other phases during normoxia. However, this difference was not observed following hypoxia, suggesting that the hormonal fluctuations that occur during the estrous cycle do not participate in the hypoxia-induced drop in Tb.

\section{Ovariectomy and hormonal replacement: ventilation, body temperature, and metabolism in normoxia and hypoxia}

Our study revealed that OVX rats under hormonal replacement showed no significant differences in the ventilatory parameters during normoxia compared to intact animals in estrous. However, OVX animals had lower a ventilatory response to hypoxia than cycling rats in estrous. Fournier et al. [17] showed that rats with reduced circulating levels of ovarian hormones (whether by ovariectomy or aging) had reduced hypoxic ventilatory responses when compared to young intact females. This result is in agreement with the findings of the present study, suggesting that ovarian hormones play a role in the ventilatory control system, providing an important signal that drives breathing. Sexual hormone receptors are expressed in the peripheral chemoreceptors of rats [23] and are localized in brainstem areas involving respiratory control $[10,20,21$, 37].

Many studies have investigated the effects of sex hormones in the ventilatory responses to hypoxia; however, only few studies were performed in female animals. Tatsumi et al. [47] found that OVX cats decreased ventilatory and carotid body responses to hypoxia. Another study [19] with anesthetized and castrated male cats showed that replacement with a combination of $\mathrm{E}_{2}$ and $\mathrm{P}$ increases both the carotid body neural output responsiveness to hypoxia and the hypoxic ventilatory response in conscious animals. The authors also demonstrated that the results were not different following replacement with progesterone or estrogen alone, indicating the importance of both for ventilatory responses to hypoxia. Additionally, Boukari et al. [9] showed that the intracerebroventricular injection of small interfering RNA (siRNA) against membrane progesterone receptors beta suppressed the ventilatory responses to hypoxia in male and female mice.

Taken together, these data suggest that sex hormones in the central and peripheral nervous system regulate processes involved in the ventilatory responses to hypoxia. Our results show a decrease of ventilatory responses to hypoxia in OVX rats compared to intact rats in the estrus phase, and that replacement with $\mathrm{E}_{2}$ and $\mathrm{E}_{2}$ plus $\mathrm{P}$ did not mimic the response as of an intact animal. It is worth noting that these regimens of hormonal replacement were effective in restoring the systemic effects of $E_{2}$ and $P$, as changes were observed in the cytology of vaginal smears, as described in [30]. Thus, although estradiol and progesterone are the main feminine gonadal hormones, it is likely that other ovarian factors may play a role in ventilation. Besides female gonadal steroids, ovarian hormones include androgens and peptide hormones, such as activin, inhibin, and follistatin [27, 31] and anti-müllerian hormone [51], which might be involved. However, there are no studies yet reporting the involvement of these hormones in ventilation. During their lifetimes, people manipulate their sexual hormone levels in different ways with oral contraceptives, hormonal replacement, etc. The respiratory consequences of these manipulations are not completely understood [3]. In this context, the present study contributes to our understanding of sex hormones and the ventilatory adjustments to hypoxia exposure; however, the mechanisms are still poorly understood.

Our experiments were performed in Wistar rats; however, we believe that this pattern of response is also valid to other rat strains. According to Hodges et al. [22], hyperventilation during hypoxia is similar among 
different female and male rat strain (Brown Norway, Dahl salt-sensitive, Fawn-hooded hypertensive, Sprague-Dawley). Further, no differences were observed among different rat strain regarding duration of the estrous cycle phases and hormonal variation [34].

In the current study, we also compared the Tbs of intact and gonadectomized animals. Our results showed that $\mathrm{Tb}$ was higher in intact animals in estrus than OVX animals $\left(\mathrm{OVX}+\mathrm{O}\right.$, OVX $+\mathrm{E}_{2}$, and $\left.\mathrm{OVX}+\mathrm{E}_{2} \mathrm{P}\right)$ during normoxia. During hypoxia, there was difference in $\mathrm{Tb}$ in OVX animals and intact rats in estrus. Based on this, we suggest that gonadal hormones do not participate in $\mathrm{Tb}$ regulation during hypoxia. It is known that hypothalamic neurons can affect thermoregulation, and that these neurons can be affected by sexual hormones. Uchida et al. [48] demonstrated that injections of $E_{2}$ in the medial preoptic nucleus (MPO) of castrated female rats maintained $\mathrm{Tb}$ constant during cold exposure. Moreover, $\mathrm{Tb}$ in castrated females that received $\mathrm{E}_{2}$ injections in the MPO was higher during cold exposure than castrated females that did not receive $E_{2}$ [48]. However, we showed that the drop in $\mathrm{Tb}$ observed during hypoxia seemed to occur despite the levels of ovarian hormones, because this response happened in the same way in both cycling and OVX animals. Nevertheless, it still remains unclear how sex hormones and castration affect body temperature and/ or body temperature regulation during hypoxia.

\section{Conclusion}

The ventilatory response to hypoxia did not change during the different phases of the estrous cycle in intact female rats. But, OVX animals showed a lower ventilatory response to hypoxia compared to intact females in estrus, suggesting that ovarian hormones exert an excitatory modulation in the respiratory response to low $\mathrm{O}_{2}$ levels. In our experimental model, replacement with $\mathrm{E}_{2}$ or a combination of $\mathrm{E}_{2}$ and $\mathrm{P}$ did not mimic the responses of an intact cycling female rat, suggesting that other ovarian factors may be involved. Moreover, on the day of estrus, animals displayed an increased body temperature, but no difference was observed during hypoxia exposure compared with other phases of estrous cycle and OVX animals. The present findings contribute to elucidate the modulation of sex hormones in the ventilation, metabolism, and body temperature control in female unanesthetized adult rats. Further investigation using female rats as an experimental model to assess the mechanisms of sex hormones in the respiratory control system might contribute to the understanding and the development of specific therapies for respiratory disorders that are sex-specific.
Acknowledgements We thank Euclides Roberto Secato and Ruither O. G. Carolino for excellent technical assistance. This work was supported by the Sao Paulo Research Foundation (FAPESP; 2012/19966-0) and Conselho Nacional de Desenvolvimento Científico e Tecnológico (CNPq - 442560/2014-1), INCT-Fisiologia Comparada. G.S.F.S. is supported by a Young Investigator Award (FAPESP; 2013/17606-9 and 2014/12190-1). D.A.M. was the recipient of a FAPESP scholarship 2016/04276-9 and CNPq 140715/2015-0.

\section{Compliance with ethical standards}

Conflict of interest The authors declare that they have no conflict of interest.

\section{References}

1. Almeida MC, Steiner AA, Coimbra NC, Branco LGS (2004) Thermoeffector neuronal pathways in fever: a study in rats showing a new role of the locus coeruleus. J Physiol 558:283-294. doi:10. 1113/jphysiol.2004.066654

2. Bartlett D, Tenney SM (1970) Control of breathing in experimental anemia. Respir Physiol 10:384-395

3. Behan M, Kinkead R (2011) Neuronal control of breathing: sex and stress hormones. Compr Physiol 1:2101-2139. doi:10.1002/cphy. c100027

4. Behan M, Zabka AG, Thomas CF, Mitchell GS (2003) Sex steroid hormones and the neural control of breathing. Respir Physiol Neurobiol 136:249-263. doi:10.1016/S1569-9048(03)00086-7

5. Berendsen HHG, Kloosterboer HJ (2003) Oestradiol and mirtazapine restore the disturbed tail-temperature of oestrogendeficient rats. Eur J Pharmacol. doi:10.1016/j.ejphar.2003.09.061

6. Biancardi V, Bícego KC, Almeida MC, Gargaglioni LH (2008) Locus coeruleus noradrenergic neurons and $\mathrm{CO} 2$ drive to breathing. Pflügers Arch Eur J Physiol 455:1119-1128. doi:10.1007/s00424007-0338-8

7. Birzniece V, Bäckström T, Johansson I-M, Lindblad C, Lundgren P, Löfgren M, Olsson T, Ragagnin G, Taube M, Turkmen S, Wahlström G, Wang M-D, Wihlbäck A-C, Zhu D (2006) Neuroactive steroid effects on cognitive functions with a focus on the serotonin and GABA systems. Brain Res Rev 51:212-239. doi: 10.1016/j.brainresrev.2005.11.001

8. Block AJ, Boysen PG, Wynne JW, Hunt LA (1979) Sleep apnea, hypopnea and oxygen desaturation in normal subjects. A strong male predominance. N Engl J Med 300:513-517. doi:10.1056/ NEJM197903083001001

9. Boukari R, Rossignol O, Marcouiller F, Bairam A, Joseph V (2016) Membrane Progestrone receptors $\alpha$ and $\beta$ contribute to regulation of breathing in adult male and female mice. A80-B VIEWING OSA Pathog Color INSTEAD BLACK WHITE Am Thorac Soc A2558-A2558

10. Brinton RD, Thompson RF, Foy MR, Baudry M, Wang J, Finch CE, Morgan TE, Pike CJ, Mack WJ, Stanczyk FZ, Nilsen J (2008) Progesterone receptors: form and function in brain. Front Neuroendocrinol 29:313-339. doi:10.1016/j.yfrne.2008.02.001

11. de Carvalho D, Bícego KC, de Castro OW, da Silva GSF, GarciaCairasco N, Gargaglioni LH (2010) Role of neurokinin-1 expressing neurons in the locus coeruleus on ventilatory and cardiovascular responses to hypercapnia. Respir Physiol Neurobiol 172:24-31. doi:10.1016/j.resp.2010.04.016

12. Dempsey JA, Olson EB, Skatrud JB (2011) Hormones and neurochemicals in the regulation of breathing. Compr Physiol. doi:10. 1002/cphy.cp030207 
13. Dombovy ML, Bonekat HW, Williams TJ, Staats BA (1987) Exercise performance and ventilatory response in the menstrual cycle. Med Sci Sports Exerc 19:111-117

14. Dutton K, Blanksby BA, Morton AR (1989) CO2 sensitivity changes during the menstrual cycle. J Appl Physiol 67:517-522

15. Edwards N, Wilcox I, Polo OJ, Sullivan CE (1996) Hypercapnic blood pressure response is greater during the luteal phase of the menstrual cycle. J Appl Physiol 81:2142-2146

16. England SJ, Farhi LE (1976) Fluctuations in alveolar CO2 and in base excess during the menstrual cycle1. Respir Physiol 26:157161. doi:10.1016/0034-5687(76)90093-1

17. Fournier S, Gulemetova R, Baldy C, Joseph V, Kinkead R (2015) Neonatal stress affects the aging trajectory of female rats on the endocrine, temperature, and ventilatory responses to hypoxia. Am J Physiol Regul Integr Comp Physiol 308:R659-R667. doi:10. 1152/ajpregu.00418.2014

18. Goldman JM, Murr AS, Cooper RL (2007) The rodent estrous cycle: characterization of vaginal cytology and its utility in toxicological studies. Birth Defects Res B Dev Reprod Toxicol 80:84-97. doi:10.1002/bdrb.20106

19. Hannhart B, Pickett CK, Moore LG (1990) Effects of estrogen and progesterone on carotid body neural output responsiveness to hypoxia. J Appl Physiol 68:1909-1916

20. Haywood SA, Simonian SX, Van der Beek EM, Bicknell RJ, Herbison AE (1999) Fluctuating estrogen and progesterone receptor expression in brainstem norepinephrine neurons through the rat estrous cycle. Endocrinology 140:3255-3263. doi:10.1210/endo. 140.7.6869

21. Helena C, Gustafsson J-A, Korach K, Pfaff D, Anselmo-Franci JA, Ogawa S (2009) Effects of estrogen receptor alpha and beta gene deletion on estrogenic induction of progesterone receptors in the locus coeruleus in female mice. Endocrine 36:169-177. doi:10. 1007/s12020-009-9207-x

22. Hodges MR, Forster HV, Papanek PE, Dwinell MR, Hogan GE (2002) Ventilatory phenotypes among four strains of adult rats. J Appl Physiol 93:974-983

23. Joseph V, Doan VD, Morency CE, Lajeunesse Y, Bairam A (2006) Expression of sex-steroid receptors and steroidogenic enzymes in the carotid body of adult and newborn male rats. Brain Res 10731074:71-82. doi:10.1016/j.brainres.2005.12.075

24. Joseph V, Niane LM, Bairam A (2012) Antagonism of progesterone receptor suppresses carotid body responses to hypoxia and nicotine in rat pups. Neuroscience 207:103-109. doi:10.1016/j. neuroscience.2012.01.041

25. Joseph V, Soliz J, Soria R, Pequignot J, Favier R, Spielvogel H, Pequignot JM (2002) Dopaminergic metabolism in carotid bodies and high-altitude acclimatization in female rats. Am J Physiol Regul Integr Comp Physiol 282:R765-R773. doi:10.1152/ ajpregu.00398.2001

26. Kent S, Hurd M, Satinoff E (1991) Interactions between body temperature and wheel running over the estrous cycle in rats. Physiol Behav 49:1079-1084

27. Knight PG, Glister C (2001) Potential local regulatory functions of inhibins, activins and follistatin in the ovary. Reproduction 121: 503-512. doi: $10.1530 / \mathrm{reprod} / 121.4 .503$

28. Lasota A, Danowska-Klonowska D (2004) Experimental osteoporosis - different methods of ovariectomy in female white rats. Rocz Akad Med Białymst 49(Suppl 1):129-131

29. Macnutt MJ, De Souza MJ, Tomczak SE, Homer JL, Sheel AW (2012) Resting and exercise ventilatory chemosensitivity across the menstrual cycle. J Appl Physiol 112:737-747

30. Marques DA, de Carvalho D, da Silva GSF, Szawka RE, AnselmoFranci JA, Bícego KC, Gargaglioni LH (2015) Ventilatory, metabolic, and thermal responses to hypercapnia in female rats: effects of estrous cycle, ovariectomy, and hormonal replacement. J Appl Physiol 119:61-68
31. Muttukrishna S, Ledger W (2001) Front matter. In: Inhibin, Act. Follistatin Hum. Reprod. Physiol. Published by imperial college press and distributed by world scientific publishing co., pp i-viii

32. Nelson HD (2008) Menopause. Lancet 371:760-770. doi:10.1016/ S0140-6736(08)60346-3

33. Österlund MK (2010) Underlying mechanisms mediating the antidepressant effects of estrogens. Biochim Biophys Acta Gen Subj 1800:1136-1144. doi:10.1016/j.bbagen.2009.11.001

34. Pascotto VM, Guerra MT, Franci JAA, de Camargo JLV, Kempinas WG, Franchi CAS (2015) Effects of a mixture of pesticides on the adult female reproductive system of Sprague-Dawley, Wistar, and Lewis rats. J Toxicol Environ Health A 78:602-616. doi:10.1080/ 15287394.2015.1010467

35. Refinetti R, Menaker M (1992) The circadian rhythm of body temperature. Physiol Behav 51:613-637

36. Saaresranta T, Polo O (2002) Hormones and breathing. Chest 122 : 2165-2182. doi:10.1378/chest.122.6.2165

37. Schlenker EH, Hansen SN (2006) Sex-specific densities of estrogen receptors alpha and beta in the subnuclei of the nucleus tractus solitarius, hypoglossal nucleus and dorsal vagal motor nucleus weanling rats. Brain Res 1123:89-100. doi:10.1016/j.brainres. 2006.09.035

38. Schoene RB, Robertson HT, Pierson DJ, Peterson AP (1981) Respiratory drives and exercise in menstrual cycles of athletic and nonathletic women. J Appl Physiol 50:1300-1305

39. Shahar E, Redline S, Young T, Boland LL, Baldwin CM, Nieto FJ, O'Connor GT, Rapoport DM, Robbins JA (2003) Hormone replacement therapy and sleep-disordered breathing. Am J Respir Crit Care Med 167:1186-1192. doi:10.1164/rccm.200210-1238OC

40. Singletary SJ, Kirsch AJ, Watson J, Karim BO, Huso DL, Hurn PD, Murphy SJ (2005) Lack of correlation of vaginal impedance measurements with hormone levels in the rat. Contemp Top Lab Anim Sci 44:37-42

41. Slatkovska L, Jensen D, Davies GAL, Wolfe LA (2006) Phasic menstrual cycle effects on the control of breathing in healthy women. Respir Physiol Neurobiol 154:379-388. doi:10.1016/j.resp. 2006.01.011

42. Smith MS, Freeman ME, Neill JD (1975) The control of progesterone secretion during the estrous cycle and early pseudopregnancy in the rat: prolactin, gonadotropin and steroid levels associated with rescue of the corpus luteum of pseudopregnancy. Endocrinology 96:219-226. doi:10.1210/endo-96-1-219

43. Szawka RE, Rodovalho GV, Monteiro PM, Carrer HF, AnselmoFranci JA (2009) Ovarian-steroid modulation of locus coeruleus activity in female rats: involvement in luteinising hormone regulation. J Neuroendocrinol 21:629-639. doi:10.1111/j.1365-2826. 2009.01880.x

44. Takano N (1985) Ventilatory responses to hypercapnia and hypoxia: the sexual difference and changes during the menstrual cycle. Kokyu To Junkan 33:17-23

45. Tatsumi K, Hannhart B, Moore LG (1995) Influences of sex steroids on ventilation and ventilatory control. Lung Biol Health Dis 79:829-864

46. Tatsumi K, Hannhart B, Pickett CK, Weil JV, Moore LG (1991) Influences of gender and sex hormones on hypoxic ventilatory response in cats. J Appl Physiol 71:1746-1751

47. Tatsumi K, Pickett CK, Jacoby CR, Weil JV, Moore LG (1997) Role of endogenous female hormones in hypoxic chemosensitivity. J Appl Physiol 83:1706-1710

48. Uchida Y, Kano M, Yasuhara S, Kobayashi A, Tokizawa K, Nagashima K (2010) Estrogen modulates central and peripheral responses to cold in female rats. J Physiol Sci 60:151-160. doi: 10.1007/s12576-009-0079-x

49. Uchida Y, Tokizawa K, Nakamura M, Mori H, Nagashima K (2010) Estrogen in the medial preoptic nucleus of the hypothalamus 
modulates cold responses in female rats. Brain Res 1339:49-59. doi:10.1016/j.brainres.2010.04.021

50. Uppari NP, Joseph V, Bairam A (2017) Respiratory responses to progesterone and allopregnanolone following chronic caffeine treatment in newborn female rats. Respir Physiol Neurobiol 240: 32-40. doi:10.1016/j.resp.2017.01.017

51. Vigier B, Picard JY, Tran D, Legeai L, Josso N (1984) Production of anti-Müllerian hormone: another homology between Sertoli and granulosa cells. Endocrinology 114:1315-1320. doi:10.1210/ endo-114-4-1315

52. Wenninger JM, Olson EB, Cotter CJ, Thomas CF, Behan M (2009) Hypoxic and hypercapnic ventilatory responses in aging male vs. aging female rats. J Appl Physiol 106:1522-1528. doi:10.1152/ japplphysiol.90802.2008
53. White DP, Douglas NJ, Pickett CK, Zwillich CW, Weil JV (1983) Sleep deprivation and the control of ventilation. Am Rev Respir Dis 128:984-986. doi:10.1164/arrd.1983.128.6.984

54. Yanase M, Tanaka H, Nakayama T (1989) Effects of estrus cycle on thermoregulatory responses during exercise in rats. Eur J Appl Physiol Occup Physiol 58:446-451

55. Young T, Peppard PE, Gottlieb DJ (2002) Epidemiology of obstructive sleep apnea: a population health perspective. Am J Respir Crit Care Med 165:1217-1239. doi:10.1164/rccm. 2109080

56. Zabka A, Behan M, Mitchell G (2001) Selected contribution: timedependent hypoxic respiratory responses in female rats are influenced by age and by the estrus cycle. J Appl Physiol 91:2831-2838 doi:10.1016/0034-5687(96)00017-5 